\title{
ДОБОВА ВАРІАБЕЛЬНІСТЬ РІВНЯ РОЗЧИННИХ ТОЛ-ПОДІБНИХ РЕЦЕПТОРІВ 2 В СИРОВАТЦІ КРОВІ ЖІНОК, ХВОРИХ НА РЕВМАТОЇДНИЙ АРТРИТ: ЗВ’ЯЗОК 3 ПЕРЕБІГОМ ЗАХВОРЮВАННЯ
}

\begin{abstract}
Вступ. Ревматоїдний артрит (РА) належить до захворювань, які асоціюються з розладами циркадних ритмів продукування прозапальних медіаторів. Імунозапальні та ангіогенні процеси в синовії активуються з участю тол-подібних рецепторів 2 (TLR2). Вивчення циркадних ритмів продукування TLR2, зокрема ї розчинної фрорми (sTLR2), що міститься в біологічних рідинах, дозволить персоніфрікувати прогноз перебігу захворювання та контроль ефективності лікування у хворих на РА.

Мета дослідження - визначити добову варіабельність рівня розчинної форми тол-подібних рецепторів 2 в сироватці крові жінок, хворих на РА, та оцінити зв'язок з перебігом захворювання.

Методи дослідження. Обстежено 173 хворих на РА (100 \% жінок) віком $(43,7 \pm 7,35)$ року та 34 жінки групи контролю віком $(42,4 \pm 10,5)$ року. Діагноз PA встановлювали за критеріями ACR/EULAR 2010. Piвень STLR2 в сироватці крові визначали о 0800; $14^{00 ;} 20^{\circ 0}$ ma $02^{00}$ за допомогою набору фрірми "Cloud-Clone Corp." (TLR2, SEA663Hu). Дослідження виконували з дотриманням біоетичних норм. Статистичну обробку результатів проводили в пакеті прикладних програм SPSS22.

Результати й обговорення. У практично здорових жінок виявлено циркадні коливання рівня STLR2 в сироватці крові з акрофразою о $08^{\circ 0}$ та батифразою о 2000. У хворих на РА встановлено циркадні особливості продукування STLR2: відмічено підвищення рівня STLR2 в сироватці крові впродовж доби (у 2 рази) порівняно з групою контролю; варіабельність рівня STLR2 в крові хворих на PA була меншою, ніж у групі контролю; спостерігали прямий зв'язок між рівнем STLR2 в сироватці крові, рентгенологічною стадією та показниками активності захворювання (DAS28, CDAI, HAQ, RAID).

Висновки. Встановлено циркадну варіабельність рівня STLR2 в сироватці крові жінок, хворих на PA, та практично здорових осіб. У хворих на РА відмічено підвищення рівня STLR2 (більш виражене вранці), що асоціюється зі збільшенням тяжкості перебігу захворювання.
\end{abstract}

КЛЮЧОВІ СЛОВА: ревматоїдний артрит; тол-подібні рецептори 2; циркадні ритми.

ВСТУП. Ревматоїдний артрит (РА) належить до мультиоракторних захворювань із складним патогенезом та остаточно не з'ясованою етіологією. Його клінічні симптоми (суглобовий біль та скутість) характеризуються добовою варіабельністю 3 найбільшим вираженням вранці $[1,2]$. Посилення симптомів РА в ранкові години пов'язане з розладами центральної та перифреричної регуляції циркадних ритмів, аномальним гіперпродукуванням прозапальних медіаторів уночі $[3,4]$. Запальні процеси в синовії активуються 3 участю тол-подібних рецепторів 2 (TLR2), які запускають сигнальні механізми експресії прозапальних цитокінів [5, 6], індукують процеси міграції та інвазії клітин [7]. Ці рецептори представлені не лише трансмембранною, а й розчинною формою (sTLR2), яку виявляють у біологічних рідинах [8]. При автоімунних захворюваннях (с) К. О. Заічко, М. А. Станіславчук, Н. В. Заічко, 2019. відмічають різноспрямовані зміни рівня STLR2 в сироватці крові - зростання при розсіяному склерозі [9] та зниження при системному червоному вовчаку [10]. В дослідах in vitro засвідчено добову ритмічність експресії MPHK TLR2 в макрофрагах селезінки тварин [11], однак циркадних ритмів продукування STLR2 не вивчали. Встановлення хронобіологічних аспектів продукування STLR2 у хворих на PA є доцільним та дозволить персоніфікувати контроль перебігу захворювання і тактику лікування в перспективі.

Мета дослідження - визначити добову варіабельність рівня розчинної фрорми тол-подібних рецепторів у сироватці крові жінок, хворих на ревматоїдний артрит, та оцінити зв'язок $з$ перебігом захворювання.

МЕТОДИ ДОСЛІДЖЕННЯ. Обстежено 173 хворих на PA (100\% жінок) віком (М $\pm \mathrm{CB})$ 
$(45,9 \pm 8,79)$ року, тривалість захворювання $(7,96 \pm 6,38)$ року. Дослідження проведено 3 дотриманням біоетичних норм відповідно до положень ВОО3, Гельсінської декларації Генеральної асамблеї Всесвітньої медичної асоціації (1989), Конвенції Ради Європи про права людини та біомедицину (1977), Міжнародної ради медичних наукових товариств, Міжнародного кодексу медичної етики (1983), діючих законів України, що засвідчив комітет з біоетики Вінницького національного медичного університету імені М. І. Пирогова.

Діагно3 РА встановлювали на основі критеріїв ACR/EULAR (2010) [12], наказу МОЗ України від 11.04 .2014 р. № 263. Його рентгенологічну стадію визначали за Steinbroker, функціональний клас (ФК) - згідно з переглянутими критеріями ACR 1991 р. [13], активність - за клінічними індексами DAS28-ШOE, CDAI, фрункціональну здатність - за індексом HAQ (україномовна версія, HAQ-DI Ukraine/Ukrainian, ID 2387), вплив захворювання на загальний стан пацієнта - за індексом RAID (Rheumatoid Arthritis Impact of Disease) [14, 15].

У зв'язку з гендерним диморфрізмом РА [16], статевими та віковими особливостями регуляції циркадних ритмів [17], у дослідженні брали участь лише особи жіночої статі віком 18-60 років 3 тривалістю захворювання $\geq 6$ місяців, кількістю болючих (КБС) та набряклих (КНС) суглобів $\geq 3$, активністю захворювання за DAS28 $>3,2$ бала. Серед обстежених хворих переважали жінки з помірною та високою активністю процесу (DAS28-ШOE >5,1 відзначали в 65,9 \% осіб), II-III рентгенологічною стадією (80,9 \%), II-III ФК (96,5\%), серопозитивним варіантом РА, зокрема в 78,6 \% осіб виявляли ревматоїдний фактор (РФ), у 83,2 \% - антитіла до циклічного цитрулінованого пептиду (АЦЦП). Позасуглобові прояви РА відмічали в 42 (24,3 \%) хворих. До групи контролю ввійшли 34 практично здорових жінки середнього віку - $(42,4 \pm 10,5)$ року.

На першому (пілотному) етапі рівень sTLR2 досліджували 4 рази на добу (о $08^{00} ; 14^{00} ; 20^{00}$ та $02^{00}$ ), на другому -2 рази (о $08^{00}$ і $\left.20^{\circ 0}\right)$. Забір крові здійснювали за допомогою вакуумних систем "Vacuette" ("Greiner Bio-One", Австрія). Перед забором крові обстежувані особи уникали фрізичних та психічних навантажень, вранці його проводили натще, надалі-щонайменше через 2 год після їди. Сироватку отримували шляхом центрисуугування цільної крові при $1500 \mathrm{~g}$ упродовж 20 хв при $18-22^{\circ} \mathrm{C}$. Проби сироватки до тестування зберігали при $-20^{\circ} \mathrm{C}$. Рівень STLR2 в сироватці крові визначали імуноферментним методом за допомогою набору "Enzyme-linked Immunosorbent Assay Kit For Toll Like Receptor 2
(TLR2)" ("Cloud-Clone Corp.", США, SEA663Hu, L170922830) відповідно до інструкції фрірмивиробника. Чутливість методу (мінімальна концентрація TLR2) $\leq 0,112$ нг/мл, коефіцієнт варіації $<10 \%$. Детекцію проводили на аналізаторі STAT-FAX 303+ (США) при довжині хвилі 450 нм (дисееренційний фрільтр - 630 нм).

Статистичну обробку отриманих результатів проводили в пакеті прикладних програм MS Excel, IBM Statistics SPSS 22. Обчислювали середню арифметичну, квадратичне відхилення та середні помилки середньої арифмметичної. Визначали медіану та інтерквартильний інтервал (Me [IQR]), 95 \% довірчий інтервал $(95 \% \mathrm{Cl})$. Достовірність відмінностей для парних та незалежних вибірок оцінювали за допомогою t-критерію Стьюдента (при параметричному розподілі), U-критерію Манна - Уїтні (при непараметричному розподілі) та за медіанним тестом, нормальність розподілу - за критерієм Шапіро - Уїлка. Для оцінки зв'язку між показниками проводили кореляційний аналіз за Спірманом. При перевірці статистичних гіпотез критичним рівнем значущості відмінностей вважали $p<0,05$.

РЕЗУЛЬТАТИ Й ОБГОВОРЕННЯ. На ПЕРШОму (пілотному) етапі дослідження у 36 хворих на PA та 34 осіб групи контролю рівень STLR2 визначали 4 рази на добу (о 08 $; 14^{00} ; 20^{00}$ та $\left.02^{00}\right)$. У жінок групи контролю було виявлено добові його коливання в сироватці крові з максимумом вранці (акрофаза) та мінімумом ввечері (батифаза) (рис. 1). У групі контролю рівень STLR2 о $08^{00}$ становив 178 [128; 223] нг/л, о $20^{00}$ $96,5[77 ; 125]$ нг/л $(\mathrm{p}<0,001)$. Удень рівень sTLR2 в сироватці крові поступово знижувався: о 1400 цей показник був меншим на $21,9 \%(p<0,05)$, ніж о $08^{00}$, а о $20^{00}$ - нижчим на $23,5 \%$, ніж о $14^{00}$ $(p<0,05)$, а вночі - зростав і о $02^{00}$ був вищим на $59,7 \%$, ніж о $20^{\circ 0}(p<0,001)$. Середньодобовий рівень STLR2 у жінок складав 145 [106; 182] нг/л, а різниця між ранковим та вечірнім рівнями ( $\triangle$ STLR2) становила $(-40,1 \pm 11,5) \%$.

У хворих на РА також виявляли добові коливання продукування STLR2 з акросразою о $08^{00}$ та батифазою о $20^{\circ 0}$, при цьому всі показники значуще перевищували такі в групі контролю. Так, у жінок з PA рівні STLR2 о $08^{00}$ та $20^{\circ 0}$ становили 329,5 [266; 395] нг/л і 240,7 [190; 292] нг/л $(p<0,001)$, середньодобовий рівень складав 296,9 [235; 348] нг/л, що було в 1,89, 2,21 та 2,0 рази більшим, ніж у здорових осіб $(\mathrm{p}<0,001)$. Рівень STLR2 у хворих на РА вдень знижувався не так суттєво: $\triangle$ STLR2 становив $(-29,7 \pm 11,2) \%$ і був в 1,35 раза меншим $(p<0,05)$, ніж у групі контролю. 


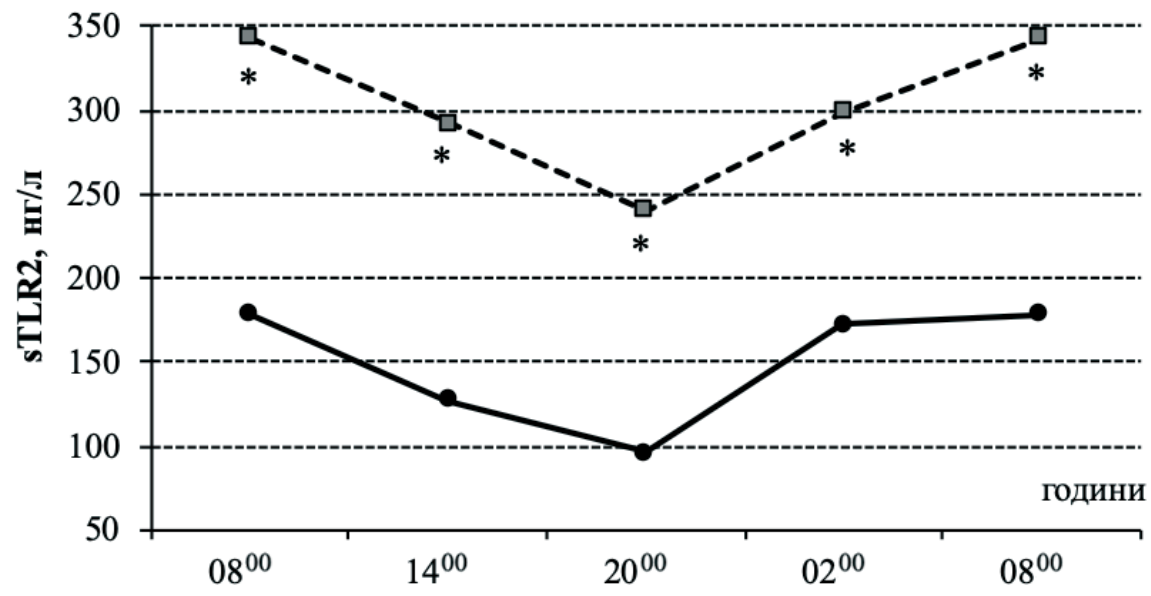

—Контроль, n=34 -

Рис. 1. Хронограма рівня розчинної форми тол-подібних рецепторів 2 в сироватці крові хворих на ревматоїдний артрит та осіб групи контролю (* - p<0,001 відносно групи контролю, медіанний тест).

На другому етапі рівень STLR2 оцінювали двічі на добу - о $08^{00}$ і $20^{00}$ (відповідно до акрофази та батифрази показника) й у загальній групі із 173 хворих виявлені закономірності підтвердились (табл. 1). Аналіз добової варіабельності показника залежно від клініко-демографічних параметрів у хворих на РА показав такі особливості: спостерігали слабку тенденцію до зростання рівня STLR2 з віком, тоді як збільшення тривалості РА, серопозитивність (за РФ і/або АЦЦП), підвищення рентгенологічної стадії захворювання та ФК асоціювались з достовірним зростанням продукції STLR2 упродовж доби. Встановлено, що в групі пацієнток з тривалістю РА до 5-ти років підвищення рівня STLR2 значною мірою асоціювалось із рентгенологічною стадією (рис. 2). Так, у хворих, які до 5-ти років досягли III стадії за Steinbroker, рівні sTLR2 о $08^{00}$ і $20^{00}$ виявились більшими на 54,6 та 88,3 \%, ніж у хворих 3 I стадією, і на 30,3 та 51,4 \% вищими, ніж у пацієнток з II стадією і тією ж тривалістю захворювання. У хворих, які до 5-ти років досягли II стадії, рівні STLR2 о $08^{00}$ і $20^{00}$ були на 18,6 та 24,3 \% вищими, ніж у пацієнток з I стадією. Показник $\Delta$ STLR2 у хворих з III стадією виявився нижчим, ніж у пацієнток з I або II стадією, і становив $(-9,80 \pm 7,63) \%$ проти $(-25,6 \pm 11,0)$ та $(-22,1 \pm 14,3) \%(p<0,01)$. Зі збільшенням тривалості РА відмінності за рівнем sTLR2 між пацієнтками 3 II та III стадіями втрачались.

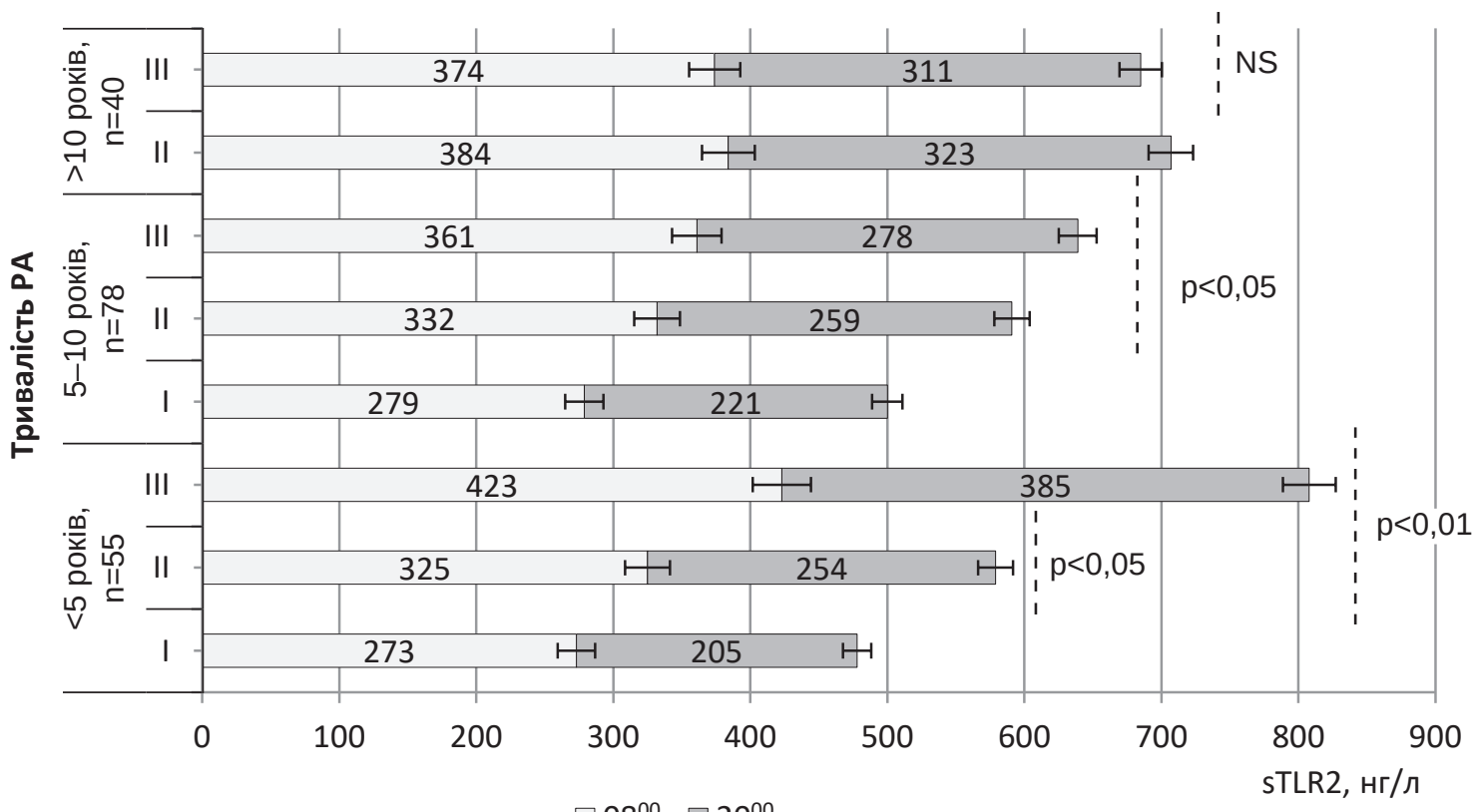

Рис. 2. Добова варіабельність рівня розчинної форми тол-подібних рецепторів 2 в сироватці крові хворих на

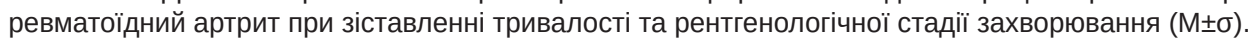


Таблиця 1 - Добова варіабельність рівня розчинної фооми тол-подібних рецепторів 2 в сироватці крові хворих на ревматоїдний артрит

\begin{tabular}{|c|c|c|c|c|}
\hline \multirow{2}{*}{\multicolumn{2}{|c|}{ Характеристика групи }} & \multicolumn{3}{|c|}{ 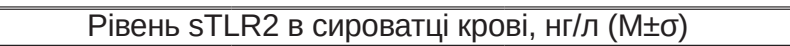 } \\
\hline & & \multirow{2}{*}{$\frac{08^{00}}{181,9 \pm 67,1}$} & \multirow{2}{*}{$\begin{array}{c}20^{00} \\
108,7 \pm 48,5\end{array}$} & \multirow{2}{*}{$\begin{array}{c}\text { середньодобовий } \\
152,6 \pm 57,4\end{array}$} \\
\hline 1 & Контроль, n=34 & & & \\
\hline \multirow[t]{2}{*}{2} & Хворі на PA, n=173 & $343,1 \pm 93,7$ & $272,3 \pm 99,2$ & $307,7 \pm 93,6$ \\
\hline & $\mathrm{p}_{2,1}$ & $<0,001$ & $<0,001$ & $<0,001$ \\
\hline \multicolumn{5}{|c|}{ Вікова група хворих на РА } \\
\hline 3 & 18-25 років, $\mathrm{n}=7$ & $319,1 \pm 95,5$ & $239,3 \pm 94,8$ & $279,2 \pm 93,7$ \\
\hline \multirow[t]{2}{*}{4} & 26-44 роки, $n=58$ & $328,4 \pm 102,3$ & $258,7 \pm 98,0$ & $293,5 \pm 97,1$ \\
\hline & $p_{3,4}$ & $>0,05$ & $>0,05$ & $>0,05$ \\
\hline \multirow[t]{3}{*}{5} & 45-60 років, $n=108$ & $352,5 \pm 88,7$ & $281,8 \pm 99,7$ & $317,1 \pm 91,2$ \\
\hline & $\mathrm{p}_{3,5}$ & $>0,05$ & $>0,05$ & $>0,05$ \\
\hline & $p_{3,4}$ & $>0,05$ & $>0,05$ & $>0,05$ \\
\hline \multicolumn{5}{|c|}{ Тривалість РА } \\
\hline 6 & $<5$ років, $\mathrm{n}=55$ & $321,5 \pm 89,1$ & $256,1 \pm 96,2$ & $288,8 \pm 90,0$ \\
\hline \multirow[t]{2}{*}{7} & 5-10 років, $\mathrm{n}=78$ & $341,0 \pm 95,2$ & $262,3 \pm 93,3$ & $301,7 \pm 91,1$ \\
\hline & $\mathrm{p}_{7,6}$ & $>0,05$ & $>0,05$ & $>0,05$ \\
\hline \multirow[t]{3}{*}{8} & $>10$ років, $\mathrm{n}=40$ & $380,6 \pm 88,3$ & $318,1 \pm 103,4$ & $349,4 \pm 92,6$ \\
\hline & $\mathrm{p}_{8,6}$ & $<0,01$ & $<0,05$ & $<0,01$ \\
\hline & $\mathrm{p}_{8,7}$ & $<0,05$ & $<0,05$ & $<0,05$ \\
\hline \multicolumn{5}{|c|}{ Імунологічна характеристика РА } \\
\hline 9 & Серопозитивність за РФ, n=136 & $346,7 \pm 93,2$ & $278,2 \pm 102,4$ & $312,5 \pm 94,7$ \\
\hline \multirow[t]{2}{*}{10} & Серопозитивність за АЦЦП, n=144 & $350,1 \pm 94,7$ & $280,6 \pm 103,3$ & $315,3 \pm 95,9$ \\
\hline & $\mathrm{p}_{9,10}$ & $>0,05$ & $>0,05$ & $>0,05$ \\
\hline \multirow[t]{3}{*}{11} & Серонегативність за АЦЦП та РФ, n=28 & $303,6 \pm 76,1$ & $238,1 \pm 76,8$ & $267,9 \pm 82,0$ \\
\hline & $p_{9,11}$ & $<0,05$ & $<0,05$ & $<0,05$ \\
\hline & $\mathrm{p}_{10,11}$ & $<0,05$ & $<0,05$ & $<0,05$ \\
\hline \multicolumn{5}{|c|}{ Рентгенологічна стадія РА за Steinbroker } \\
\hline 7 & I стадія, $\mathrm{n}=33$ & $303,4 \pm 93,1$ & $222,8 \pm 198,0$ & $263,1 \pm 84,1$ \\
\hline \multirow[t]{2}{*}{8} & II стадія, n=72 & $335,5 \pm 93,3$ & $267,8 \pm 102,2$ & $301,6 \pm 95,4$ \\
\hline & $\mathrm{p}_{7,8}$ & $>0,05$ & $<0,05$ & $<0,05$ \\
\hline \multirow[t]{3}{*}{9} & III стадія, n=68 & $370,4 \pm 87,8$ & $301,1 \pm 94,0$ & $335,8 \pm 87,4$ \\
\hline & $\mathrm{p}_{7,9}$ & $<0,01$ & $<0,01$ & $<0,01$ \\
\hline & $\mathrm{p}_{8,9}$ & $<0,05$ & $<0,05$ & $<0,05$ \\
\hline \multicolumn{5}{|c|}{ Функціональний клас } \\
\hline 10 & $\Phi \mathrm{K} I, \mathrm{n}=6$ & $269,5 \pm 54,0$ & $188,5 \pm 33,6$ & $229,0 \pm 37,1$ \\
\hline \multirow[t]{2}{*}{11} & ФK II, n=108 & $332,2 \pm 91,2$ & $253,8 \pm 86,3$ & $293,0 \pm 85,5$ \\
\hline & $p_{10,11}$ & $<0,05$ & $<0,01$ & $<0,05$ \\
\hline \multirow[t]{3}{*}{12} & ФK III, n=59 & $370,5 \pm 95,0$ & $314,7 \pm 110,3$ & $342,6 \pm 100,6$ \\
\hline & $p_{10,12}$ & $<0,001$ & $<0,001$ & $<0,001$ \\
\hline & $\mathrm{p}_{11,12}$ & $<0,05$ & $<0,01$ & $<0,01$ \\
\hline
\end{tabular}

За результатами ROC-аналізу (рис. 3), ранковий рівень STLR2 >375 нг/л був предиктором прискореної рентгенологічної прогресії РА 3 чутливістю 0,875 та специфрічністю 0,787 (площа під ROC-кривою - 0,852; 95 \% Cl 0,702-0,990; $\mathrm{p}<0,002)$. У хворих на PA з рівнем sTLR2 $>375$ нг/л утричі зростали шанси досягнути IIIII стадії за Steinbroker до 5-ти років (OR=3,32, $95 \%$ Cl 0,96-11,47).

За результатами квартильного аналізу, підвищення ранкового рівня STLR2 асоціювалось зі збільшенням активності захворювання згідно 3 індексами DAS28-ШOE, DAS28-СРБ, CDAI, HAQ та RAID (табл. 2). Так, у квартилі Q (STLR2 $^{2}$ $>406$ нг/л) відсоток пацієнток з DAS28-ШОЕ >5,1, HAQ >2 i RAID >6 був вищим у 3,62; 4,46 та 4,50 раза, ніж у квартилі $\mathrm{Q}_{1}$ (<265 нг/л). Кореля- ційний аналіз підтвердив достовірний зв'язок між ранковим рівнем STLR2 та індексами активносTi PA - DAS28-WOE i CDAI $\left(r_{\mathrm{Sp}}=0,60-0,64\right.$, $p<0,001)$, RAID $\left(r_{s p}=0,54, p<0,001\right)$ та HAQ $\left(r_{s p}=0,41, p<0,01\right)$

Встановлене зростання рівня STLR2 в сироватці крові хворих на РА узгоджується з результатами інших досліджень. Як відомо, STLR2 продукуються шляхом відщеплення ектодомену від клітинних рецепторів з участю металопротеїназ за умов прозапальної стимуляції [8]. У хворих на PA відмічено підвищення експресії TLR2 в моноцитах крові та синовіальної рідини, що супроводжується збільшенням продукції прозапальних цитокінів (інтерлейкінів $1 \beta, 6$, срактора некрозу пухлини $\alpha$ ) [18], що, очевидно, може зумовлювати зростання рівня STLR2 в біологіч- 
Таблиця 2 - Частота виявлення високої активності захворювання у хворих на ревматоїдний артрит відповідно до квартильного розподілу рівня розчинної форми тол-подібних рецепторів 2 в сироватці крові $\left(08^{00}\right)$

\begin{tabular}{|l|c|c|c|c|c|}
\hline \multirow{2}{*}{ Квартиль sTLR2 } & \multicolumn{4}{|c|}{ Кількість Хворих з високою активністю РА, $\mathrm{n}(\%)$} \\
\cline { 2 - 6 } & $\begin{array}{c}\text { DAS28-ШОЕ } \\
>5,1\end{array}$ & $\begin{array}{c}\text { DAS28-СРБ } \\
>5,1\end{array}$ & СDAI >22 & НАQ >2 & RAID >6 \\
\hline $\mathrm{Q}_{1}(<265 \mathrm{нг/л),n=42}$ & $11(26,2 \%)$ & $11(26,2 \%)$ & $15(35,7 \%)$ & $3(7,1 \%)$ & $8(19,0 \%)$ \\
\hline $\mathrm{Q}_{2}(265-335 \mathrm{Hг} / л), \mathrm{n}=45$ & $27(60,0 \%)$ & $21(46,7 \%)$ & $28(62,2 \%)$ & $4(8,9 \%)$ & $16(35,6 \%)$ \\
\hline $\mathrm{Q}_{3}(336-405 \mathrm{Hг} / л), \mathrm{n}=45$ & $37(82,2 \%)$ & $31(68,9 \%)$ & $39(86,7 \%)$ & $10(22,2 \%)$ & $27(60,0 \%)$ \\
\hline $\mathrm{Q}_{4}(>406 \mathrm{нг} / л), \mathrm{n}=41$ & $39(95,1 \%)$ & $38(92,7 \%)$ & $40(97,6 \%)$ & $13(31,7 \%)$ & $35(85,4 \%)$ \\
\hline $\mathrm{p}_{2,1}$ & $<0,05$ & $<0,05$ & $<0,05$ & $>0,05$ & $>0,05$ \\
\hline $\mathrm{p}_{3,1}$ & $<0,001$ & $<0,05$ & $<0,001$ & $<0,05$ & $<0,001$ \\
$\mathrm{p}_{3,2}$ & $<0,05$ & $<0,05$ & $<0,05$ & $>0,05$ & $<0,05$ \\
\hline $\mathrm{p}_{4,1}$ & $<0,001$ & $<0,001$ & $<0,001$ & $<0,05$ & $<0,001$ \\
$\mathrm{p}_{4,2}$ & $<0,01$ & $<0,01$ & $<0,05$ & $<0,05$ & $<0,001$ \\
$\mathrm{p}_{4,3}$ & $>0,05$ & $<0,05$ & $>0,05$ & $>0,05$ & $<0,05$ \\
\hline
\end{tabular}

Примітка. Достовірність відмінностей визначено за точним методом Фішера (Fisher exact test, 2-tailed).

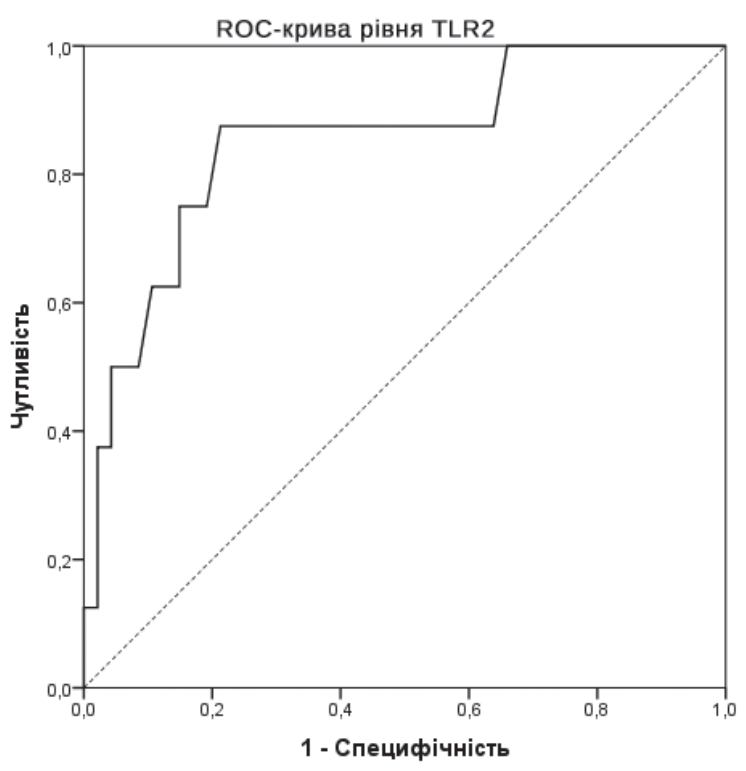

Pис. 3. ROC-крива рівня розчинної фоории тол-подібних рецепторів 2 в сироватці крові $\left(08^{00}\right)$ як предиктора швидкого прогресування ревматоїдного артриту (за рентгенологічною стадією).

них рідинах. Тол-подібні рецептори 2 здатні стимулювати ангіогенез через експресію васкулоендотеліального фрактора (VEGF) [19] та рецепторів ангіопоетину Tiе2 [20], посилювати остеокластогенез [21]. Таким чином, підвищення добової продукції sTLR2 у хворих на PA можна вважати одним з чинників прогресування імунозапальних та остеодеструктивних змін у суглобах. Зауважимо, що, у зв'язку зі статевим диморфрізмом біологічних ритмів та імунної відповіді, циркадні особливості продукування STLR2, виявлені в жінок, хворих на РА, доцільно перевірити в чоловіків.

ВИСНОВКИ. 1. У хворих на ревматоїдний артрит встановлено такі циркадні особливості продукування STLR2: мінімальний рівень STLR2 реєструють увечері (о $\left.20^{\circ 0}\right)$, максимальний уранці (о 08 $\left.{ }^{\circ 0}\right)$; відмічають значуще підвищення рівня STLR2 в сироватці крові впродовж усієї доби (в середньому вдвічі) порівняно з групою контролю; ввечері зниження рівня STLR2 ( $\triangle$ sTLR2) у хворих на ревматоїдний артрит $€$ меншим (в 1,35 раза) порівняно з групою контролю.

2. Зростання продукції sTLR2 асоціюється зі збільшенням рентгенологічної стадії та підвищенням активності ревматоїдного артриту (за DAS28-WOE, DAS28-CPБ, CDAI, HAQ, RAID) i $\epsilon$ більш значним у серопозитивних пацієнток.

3. У хворих на ревматоїдний артрит із тривалістю захворювання до 5-ти років високий рівень STLR2 вранці (>375 нг/л) є предиктором швидкої рентгенологічної прогресії з чутливістю 87,5 \% і специсрічністю 78,7 \%.
СПИСОК ЛІТЕРАТУРИ

1. Cutolo M. Glucocorticoids and chronotherapy in rheumatoid arthritis / M. Cutolo // RMD Open. - 2016. 2, No. 1. e000203. doi: $10.1136 /$ rmdopen-2015-000203

2. Gibbs J. The role of the circadian clock in rheumatoid arthritis / J. Gibbs, D. Ray // Arthritis Research
\& Therapy. - 2013. - 15, No.1. - P. 205. doi: 10.1186/ ar4146

3. Effect of novel therapeutic glucocorticoids on circadian rhythms of hormones and cytokines in rheumatoid arthritis / J. Kirwan, L. Clarke, L. Hunt [et al.] // 
Annals of The New YorkAcademy of Sciences. - 2010. 1193, No. 1. - P. 127-133.

4. Sierakowski S. Morning symptoms in rheumatoid arthritis: a defining characteristic and marker of active disease / S. Sierakowski, M. Cutolo // Scandinavian Journal of Rheumatology. - 2011. -40, No. 125. - P. 1-5. doi: 10.3109/03009742.2011.566433

5. Expression of Toll-like receptors 2 and 4 in rheumatoid synovial tissue and regulation by proinflammatory cytokines interleukin-12 and interleukin-18 via interferon-y/ T. Radstake, M. Roelofs, Y. Jenniskens [et al.] // Arthritis \& Rheumatism. - 2004. - 50, No. 12. - P. 3856-3865.

6. Toll-like receptors expressed by synovial fibroblasts perpetuate Th1 and Th17 cell responses in rheumatoid arthritis / F. Hu, Y. Li, L. Zheng [et al.] // Plos ONE. 2014. - 9, No. 6. - e100266. doi: 10.1371/journal. pone.0100266

7. Toll-like receptor 2 (TLR2) induces migration and invasive mechanisms in rheumatoid arthritis / T. McGarry, D. Veale, W. Gao [et al.] // Arthritis Research \& Therapy. 2015. - 17, No. 1. doi: 10.1186/s13075-015-0664-8

8. Metalloproteinase-dependent TLR2 ectodomain shedding is involved in soluble toll-like receptor 2 (sTLR2) production / P. Langjahr, D. Díaz-Jiménez, M. De la Fuente [et al.] // Plos ONE. -2014. - 9, No. 12. e104624. doi: 10.1371/journal.pone.0104624

9. The soluble form of toll-like receptor 2 is elevated in serum of multiple sclerosis patients: a novel potential disease biomarker / M. Hossain, E. Morandi, R. Tanasescu [et al.] // Frontiers In Immunology. - 2018. No. 9. doi: 10.3389/fimmu.2018.00457

10. Houssen M. Serum soluble toll-like receptor 2: a novel biomarker for systemic lupus erythematosus disease activity and lupus-related cardiovascular dysfunction / M. Houssen, R. El-Mahdy, D. Shahin // International Journal of Rheumatic Diseases. - 2014. 19, No. 7. - P. 685-692.

11. Daily oscillations in expression and responsiveness of Toll-like receptors in splenic immune cells / A. Silver, S. Buckley, M. Hughes [et al.] // Heliyon. - 2018. - 4, No. 3, e00579. doi: 10.1016/j.heliyon.2018.e00579

12. Rheumatoid arthritis classification criteria: an American College of Rheumatology/European League Against Rheumatism collaborative initiative / D. Aletaha, T. Neogi, A. J. Silman [et al.] // Ann. Rheum. Dis. - 2010. 69. - P. 1580-1588.
13. The American College of Rheumatology 1991 revised criteria for the classification of global functional status in rheumatoid arthritis / M. Hochberg, R. Chang, I. Dwosh [et al.] // Arthritis \& Rheumatism. - 1992. - 35, No. 5. - P. 498-502.

14. Станіславчук М. Крос-культуральна адаптація та валідизація україномовної версії RAID у хворих на ревматоїдний артрит / М. Станіславчук, К. Заічко // Укр. ревматол. журн. - 2019. - 3, № 77. - Р. 51-55.

15. Finalisation and validation of the rheumatoid arthritis impact of disease score, a patient-derived composite measure of impact of rheumatoid arthritis: a EULAR initiative / L. Gossec, S. Paternotte, G. Aanerud [et al.] // Annals of The Rheumatic Diseases. -2011. - 70, No. 6. - P. 935-942.

16. Women, men, and rheumatoid arthritis: analyses of disease activity, disease characteristics, and treatments in the QUEST-RA Study / T. Sokka, S. Toloza, M. Cutolo [et al.] //Arthritis Research \& Therapy. - 2009. - 11, No. 7. doi:10.1186/ar2591.

17. Yan L. Neuroendocrine underpinnings of sex differences in circadian timing systems / L. Yan, R. Silver // The Journal of Steroid Biochemistry and Molecular Biology. - 2016. - 160. - P. 118-126.

18. Overexpression of TLR2 and TLR9 on monocyte subsets of active rheumatoid arthritis patients contributes to enhance responsiveness to TLR agonists / P. Lacerte, A. Brunet, B. Egarnes [et al.] // Arthritis Research \& Therapy. - 2016. - 18, No. 1. doi: 10.1186/s13075-0150901-1

19. Toll-like receptor 2 ligand mediates the upregulation of angiogenic factor, vascular endothelial growth factor and interleukin-8/CXCL8 in human rheumatoid synovial fibroblasts / M. Cho, J. Ju, H. Kim [et al.] // Immunology Letters. - 2007. - 108, No. 2. - P. 121-128. doi: 10.1016/j.imlet.2006.11.005

20. Toll-like receptor 2 induced angiogenesis and invasion is mediated through the tie 2 signalling pathway in rheumatoid arthritis / T. Saber, D. Veale, E. Balogh [et al.] // Plos ONE. - 2011. - 6, No. 8. e23540. doi: 10.1371/journal.pone.0023540

21. The effect of vascular endothelial growth factor on osteoclastogenesis in rheumatoid arthritis / H. Kim, K. Kim, B. Kim [et al.] // PLOS ONE. - 2015. - 10, No. 4. e0124909. doi: 10.1371/journal.pone.0124909

\section{REFERENCES}

1. Cutolo, M. (2016). Glucocorticoids and chronotherapy in rheumatoid arthritis. RMD Open, 2 (1), e000203. doi: 10.1136/rmdopen-2015-000203. [PubMed].

2. Gibbs, J., \& Ray, D. (2013). The role of the circadian clock in rheumatoid arthritis. Arthritis Research \& Therapy, 15 (1), 205. doi: 10.1186/ar4146. [PubMed].

3. Kirwan, J., Clarke, L., Hunt, L., Perry, M., Straub, R., \& Jessop, D. (2010). Effect of novel therapeutic glucocorticoids on circadian rhythms of hormones and cytokines in rheumatoid arthritis. Annals of The New York Academy Of Sciences, 1193 (1), 127-133. doi: 10.1111/ j.1749-6632.2009.05289.x. [PubMed].
4. Sierakowski, S., \& Cutolo, M. (2011). Morning symptoms in rheumatoid arthritis: a defining characteristic and marker of active disease. Scandinavian Journal of Rheumatology, 40 (125), 1-5. doi: 10.3109/03009742. 2011.566433. [PubMed].

5. Radstake, T., Roelofs, M., Jenniskens, Y., OppersWalgreen, B., van Riel, P., \& Barrera, P. (2004). Expression of Toll-like receptors 2 and 4 in rheumatoid synovial tissue and regulation by proinflammatory cytokines interleukin-12 and interleukin-18 via interferon-? Arthritis \& Rheumatism, 50 (12), 3856-3865. doi: 10.1002/art.20678. [PubMed] 
6. Hu, F., Li, Y., Zheng, L., Shi, L., Liu, H., \& Zhang, X. (2014). Toll-Like receptors expressed by synovial fibroblasts perpetuate Th1 and Th17 cell responses in rheumatoid arthritis. Plos ONE, 9 (6), e100266. doi: 10.1371/ journal.pone.0100266. [PubMed].

7. McGarry, T., Veale, D., Gao, W., Orr, C., Fearon, U., \& Connolly, M. (2015). Toll-like receptor 2 (TLR2) induces migration and invasive mechanisms in rheumatoid arthritis. Arthritis Research \& Therapy, 17 (1). doi: 10.1186/ s13075-015-0664-8. [PubMed].

8. Langjahr, P., Díaz-Jiménez, D., De la Fuente, M., Rubio, E., Golenbock, D., \& Bronfman, F. (2014). Metalloproteinase-dependent TLR2 ectodomain shedding is involved in soluble toll-like receptor 2 (sTLR2) production. Plos ONE, 9 (12), e104624. doi: 10.1371/journal. pone.0104624. [PubMed].

9. Hossain, M., Morandi, E., Tanasescu, R., Frakich, N., Caldano, M., \& Onion, D. (2018). The soluble form of toll-like receptor 2 is elevated in serum of multiple sclerosis patients: a novel potential disease biomarker. Frontiers in Immunology, 9. doi: 10.3389/fimmu.2018. 00457. [PubMed].

10. Houssen, M., El-Mahdy, R., \& Shahin, D. (2014). Serum soluble toll-like receptor 2: a novel biomarker for systemic lupus erythematosus disease activity and lupusrelated cardiovascular dysfunction. International Journal of Rheumatic Diseases, 19 (7), 685-692. doi: 10.1111/1756185x.12452. [PubMed].

11. Silver, A., Buckley, S., Hughes, M., Hastings, A., Nitabach, M., \& Fikrig, E. (2018). Daily oscillations in expression and responsiveness of Toll-like receptors in splenic immune cells. Heliyon, 4 (3), e00579. doi: 10.1016/j.heliyon.2018.e00579. [PubMed].

12. Aletaha, D., Neogi, T., Silman, A.J., Funovits, J., Felson, D.T., \& Bingham, C.O. (2010) Rheumatoid arthritis classification criteria: an American College of Rheumatology/European League Against Rheumatism collaborative initiative. Ann. Rheum. Dis., (69), 1580-1588. [PubMed].

13. Hochberg, M., Chang, R., Dwosh, I., Lindsey, S., Pincus, T., \& Wolfe, F. (1992). The American College of Rheumatology 1991 revised criteria for the classification of global functional status in rheumatoid arthritis. Arthritis \& Rheumatism, 35 (5), 498-502. doi: 10.1002/ art.1780350502. [PubMed].

14. Stanislavchuk, M., \& Zaichko, K. (2019) Kroskulturalna adaptatsiia ta validyzatsiia ukrainomovnoi versii
RAID u khvorykh na revmatoidnyi artryt [Cross-cultural adaptation and validation of the Ukrainian version of RAID in patients with rheumatoid arthritis]. Ukrainskyi revmatolohichnyi zhurnal - Ukrainian Journal of Rheumatology, 3 (77), 51-55 [in Ukrainian]

15. Gossec, L., Paternotte, S., Aanerud, G., Balanescu, A., Boumpas, D., \& Carmona, L. (2011). Finalisation and validation of the rheumatoid arthritis impact of disease score, a patient-derived composite measure of impact of rheumatoid arthritis: a EULAR initiative. Annals of the Rheumatic Diseases, 70 (6), 935-942. doi: 10.1136/ard.2010.142901. [PubMed].

16. Sokka, T., Toloza, S., Cutolo, M., Kautiainen H., Makinen H., \& Gogus F. (2009). Women, men, and rheumatoid arthritis: analyses of disease activity, disease characteristics, and treatments in the QUEST-RA Study. Arthritis Research \& Therapy, 11 (7). doi:10.1186/ar2591. [PubMed].

17. Yan, L., \& Silver, R. (2016). Neuroendocrine underpinnings of sex differences in circadian timing systems. The Journal of Steroid Biochemistry and Molecular Biology, 160, 118-126. doi: 10.1016/j.jsbmb.2015.10.007. [PubMed].

18. Lacerte, P., Brunet, A., Egarnes, B., Duchêne, B., Brown, J., \& Gosselin, J. (2016). Overexpression of TLR2 and TLR9 on monocyte subsets of active rheumatoid arthritis patients contributes to enhance responsiveness to TLR agonists. Arthritis Research \& Therapy, 18 (1). doi: 10.1186/s13075-015-0901-1. [PubMed].

19. Cho, M., Ju, J., Kim, H., Oh, H., Kang, C., \& Jhun, J. (2007). Toll-like receptor 2 ligand mediates the upregulation of angiogenic factor, vascular endothelial growth factor and interleukin-8/CXCL8 in human rheumatoid synovial fibroblasts. Immunology Letters, 108 (2), 121-128. doi: 10.1016/j.imlet.2006.11.005. [PubMed].

20. Saber, T., Veale, D., Balogh, E., McCormick, J., NicAnUltaigh, S., Connolly, M., \& Fearon, U. (2011). Tolllike receptor 2 induced angiogenesis and invasion is mediated through the tie2 signalling pathway in rheumatoid arthritis. Plos ONE, 6 (8), e23540. doi: 10.1371/ journal.pone.0023540. [PubMed].

21. Kim, H., Kim, K., Kim, B., Cho, M., \& Lee, S. (2015). The effect of vascular endothelial growth factor on osteoclastogenesis in rheumatoid arthritis. PLOS ONE, 10(4), e0124909. doi: 10.1371/journal.pone. 0124909. [PubMed].

Е. А. Заичко, Н. А. Станиславчук, Н. В. Заичко ВИННИЦКИЙ НАЦИОНАЛЬНЫЙ МЕДИЦИНСКИЙ УНИВЕРСИТЕТ ИМЕНИ Н. И. ПИРОГОВА

\section{СУТОЧНАЯ ВАРИАБЕЛЬНОСТЬ УРОВНЯ РАСТВОРИМЫХ ТОЛЛ-ПОДОБНЫХ РЕЦЕПТОРОВ 2 В СЫВОРОТКЕ КРОВИ ЖЕНЩИН, БОЛЬНЫХ РЕВМАТОИДНЫМ АРТРИТОМ: СВЯЗЬ С ТЕЧЕНИЕМ ЗАБОЛЕВАНИЯ}

\section{Резюме}

Вступление. Ревматоидный артрит (РА) относится к заболеваниям, которые ассоциируются с расстройствами циркадных ритмов продуцирования провоспалительных медиаторов. Иммуновоспалительные и ангиогенные процессы в синовии ативируются при участии толл-подобных рецепторов 2 
(TLR2). Изучение циркадных ритмов продуцирования TLR2, в частности их растворимой фрормы (STLR2), содержащейся в биологических жидкостях, позволит персонифицировать прогноз течения заболевания и контроль эфрфективности лечения у больных РА.

Цель исследования - определить суточную вариабельность уровня растворимой фрормы толлподобных рецепторов 2 в сыворотке крови женщин, больных РА, и оценить связь с течением заболевания.

Методы исследования. Обследовано 173 больных РА (100 \% женщин) в возрасте $(43,7 \pm 7,35)$ лет и 34 женщины группы контроля в возрасте $(42,4 \pm 10,5)$ лет. Диагноз РА устанавливали по критериям ACR/ EULAR 2010. Уровень STLR2 в сыворотке крови определяли в $08^{00} ; 14^{00} ; 20^{\circ 0}$ и $02^{00}$ с помощью набора фрирмы "Cloud-Clone Corp." (TLR2, SEA663Hu). Исследование выполняли с соблюдением биоэтических норм. Cтатистическую обработку результатов проводили в пакете прикладных программ SPSS22.

Результаты и обсуждение. У практически здоровых женщин обнаружены циркадные колебания уровня STLR2 в сыворотке крови с акрофразой в $08^{\circ 0}$ и батифразой в 2000. У больных PА установлено циркадные особенности продуцирования STLR2: отмечено повышение уровня STLR2 в сыворотке крови в течение суток (в 2 раза) по сравнению с группой контроля; вариабельность уровня sTLR2 в крови больных PA была меньше, чем в группе контроля; наблюдали прямую связь между уровнем STLR2 в сыворотке крови, рентгенологической стадией и показателями активности заболевания (DAS28, CDAl, HAQ, RAID).

Выводы. Установлено циркадную вариабельность уровня STLR2 в сыворотке крови женщин, больных PA, и практически здоровых лиц. У больных PA отмечено повышение уровня STLR2 (более выразительное утром), что ассоциируется с увеличением тяжести течения заболевания.

КЛЮЧЕВЫЕ СЛОВА: ревматоидный артрит; толл-подобные рецепторы 2; циркадные ритмы.

K. O. Zaichko, M. A. Stanislavchuk, N. V. Zaichko

NATIONAL PIROGOV MEMORIAL MEDICAL UNIVERSITY, VINNYTSYA

\section{DAILY VARIABILITY IN SOLUBLE TOLL-LIKE RECEPTORS 2 IN THE SERUM OF WOMEN WITH RHEUMATOID ARTHRITIS: ITS ASSOCIATION WITH THE DISEASE}

\section{Summary}

Introduction. Rheumatoid arthritis $(R A)$ is a disease that associated with disorders of the circadian rhythms of proinflammatory mediators. Activation of immunoinflammatory and angiogenic processes in the synovium occurs with the participation of toll-like receptors 2 (TLR2). The study of the circadian rhythms of TLR2 production, in particular their soluble form (STLR2) contained in biological fluids, will allow to personalize the prognosis of the disease and control the effectiveness of treatment in patients with RA.

The aim of the study - to find out the daily variability of STLR2 in the serum of women with RA and to evaluate its association with the course of the disease.

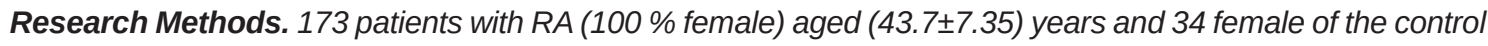
groups aged (42.4 \pm 10.5$)$ years were examined. The diagnosis of RA was established by ACR/EULAR criteria 2010. Serum STLR2 level was determined at $08^{00} ; 14^{\circ 0} ; 20^{\circ 0}$ and $02^{\circ 0}$ by Cloud-Clone Corp. (TLR2, SEA663Hu). The study was conducted in compliance with bioethical standards. Statistical processing of the results was performed in the SPSS22 application package.

Results and Discussion. Circadian oscillations of serum STLR2 level with acrophase at $8^{\circ 0}$ and batiphase at $20^{\circ 0}$ were found in healthy women. Patients with RA have circadian features of sTLR2 production: there is an increase in serum STLR2 during the day (2 times) compared to the control group; variability in blood levels of sTLR2 in patients with RA is less significant, than in the control group; it was established a direct relationship between serum STLR2 level, radiographic stage, and disease activity rates (DAS28, CDAI, HAQ, RAID).

Conclusions. Circadian variability of STLR2 level in serum of women with RA and practically healthy subjects was established. In patients with RA, there is an increase in STLR2 levels (more pronounced in the morning), which is associated with an increase in the severity of the disease.

KEY WORDS: rheumatoid arthritis; toll-like receptor 2; circadian rhythms.

Адреса для листування: Н. В. Заічко, Вінницький національний медичний університет імені М. І. Пирогова, вул. Пирогова, 56, Вінниця, 21018, Україна, е-mail: zaichkonv@gmail.com. 